\title{
PENGARUH MODEL PEMBELAJARAN CONNECTED MATHEMATICS PROJECT (CMP) TERHADAP KEMAMPUAN PEMECAHAN MASALAH MATEMATIS SISWA SMP
}

\author{
Sri Rahmawati Fitriatien ${ }^{1}$, Ibut Priono Leksono ${ }^{2}$, Prayogo ${ }^{3}$ \\ Pendidikan Matematika, Universitas PGRI Adi Buana Surabaya ${ }^{1,2,3}$ \\ Email: rahmawatien.srf@unipasby.ac.id¹, ibutpriono@gmail.com², \\ prayogounipa@gmail.com³
}

\begin{abstract}
Abstrak. Penelitian ini dilatar belakangi oleh masih kurangnya kemampuan pemecahan masalah matematis siswa dan terdapat banyak siswa yang kesulitan belajar matematika. Hal tersebut disebabkan oleh pembelajaran yang hanya berpusat pada guru. Upaya yang dapat dilakukan agar proses pembelajaran di kelas dapat meningkatkan kemampuan pemecahan masalah siswa diantaranya dengan memilih dan menggunakan model pembelajaran yang relevan. Salah satu model pembelajaran yang relevan tersebut adalah model pembelajaran Connected Mathematics Project (CMP). Penelitian ini bertujuan untuk mengetahui pengaruh model pembelajaran CMP terhadap kemampuan pemecahan masalah matematis siswa kelas VIII SMPN 12 Surabaya. Metode yang digunakan pada penelitian ini adalah metode kuantitatif. Sampel penelitian diperoleh sebanyak dua kelas dengan teknik random sampling yang terdiri dari kelas eksperimen dan kelas kontrol, masing-masing sebanyak 37 siswa. Analisis data yang digunakan pada penelitian ini yaitu uji-t. Hasil penelitian dengan menggunakan uji-t tersebut menunjukkan bahwa terdapat pengaruh model pembelajaran CMP terhadap hasil belajar siswa kelas VIII SMP Negeri 12 Surabaya tahun ajaran 2019/2020 pada materi Sistem Persamaan Linear Dua Variabel (SPLDV). Selain itu kemampuan pemecahan masalah matematis siswa yang meliputi memahami masalah pada kelas eksperimen lebih tinggi daripada kelas kontrol.
\end{abstract}

\section{Kata kunci: Connected Mathematics Project (CMP), Mathematical Problem Solving Ability}

\begin{abstract}
The research was conducted in students' mathematical problem - solving skills and there are many students who have difficulty learning mathematics. This is due to the teacher - centered learning. Efforts that can be made to the learning process in the classroom can improve students ' problem - solving skills by selecting and using the relevant learning model. One such relevant learning model is the Connected Mathematics Project (CMP) learning model. The research problem was formulized in "is there any influence of the Connected Mathematics Project (CMP) learning model to the mathematical problem - solving skills of SMP students?". This research aims to determine the influence of CMP learning model to the mathematical problem solving skills of grade VIII SMPN 12 Surabaya. The research method was plied in quantitative methods. Research samples were acquired by two classes with random sampling techniques consisting of experimental classes and control classes, each as much as 37 students. Analysis of the data used in this study is test-T. The results of the study using the test-T showed that there was a influence of the CMP learning model of students learning outcomes of class VIII SMP Negeri 12 Surabaya year 2019/2020 of The System Material of Two-Variable Linear Equations (SPLDV). In addition, students' mathematical problem solving capabilities include understanding the problems in the experiment class higher than the control class.
\end{abstract}

Keywords: Connected Mathematics Project (CMP), Mathematical Problem Solving Ability

\section{A. Pendahuluan}

Matematika memiliki peran yang sangat penting dalam kehidupan manusia. Dalam pembelajaran matematika, siswa dituntut untuk menguasai semua kemampuan matematis yang diharapkan. Pemecahan masalah merupakan salah satu kemampuan yang harus dikuasai siswa dalam pembelajaran matematika. (NCTM, 1989) mengemukakan bahwa pemecahan masalah menjadi tujuan utama dari semua pembelajaran matematika dan merupakan bagian tak 
terpisahkan dari semua aktivitas matematika. Pemecahan masalah penting dalam matematika karena dalam proses pembelajaran siswa dimungkinkan memperoleh pengalaman menggunakan pengetahuan yang dimiliki sebelumnya untuk diterapkan ke dalam situasi yang baru . Berdasarkan hasil observasi penulis, pembelajaran matematika lebih berpusat pada guru. Guru lebih banyak berperan dalam pembelajaran dengan menyampaikan materi melalui pembelajaran konvensional sehingga siswa hanya mendengarkan apa yang telah disampaikan guru tanpa berperan aktif dalam pembelajaran. Kondisi siswa yang pasif, jelas tidak menguntungkan terhadap peningkatan kemampuan pemecahan masalah siswa dalam matematika. Untuk itu perlu usaha guru agar siswa belajar secara aktif. Siswa harus mampu mengungkapkan gagasan dan ide-ide matematis mereka.

Selain itu kebanyakan siswa menganggap matematika adalah mata pelajaran yang sulit dipahami dan kemampuan pemecahan masalah siswa pada mata pelajaran matematika masih kurang (Indriani et al., 2019). Pada saat menyelesaikan soal, siswa melakukan banyak kesalahan sehingga menyebabkan kegagalan pada proses pemecahan masalah (Jatmiko, 2018). Perbedaan proses pemecahan masalah antar siswa di kelas menyebabkan terjadinya kesalahan siswa dalam menyelesaikan soal-soal matematika sehingga perlu diketahui bagaimana proses pemecahan masalah yang dilakukan siswa. Dengan diketahuinya proses pemecahan masalah yang dilakukan siswa, maka guru pada saat proses pembelajaran berlangsung dapat membantu mereka yang mengalami kesulitan. Guru menjadi fasilitator bagi siswa agar mereka dapat mengungkapkan gagasan dan ide-ide matematisnya untuk dapat menyelesaikan masalah yang sedang dihadapinya. Hal ini sesuai dengan salah satu tujuan pembelajaran matematika yang ditetapkan oleh NCTM yaitu pemecahan masalah harus dikuasai siswa dalam pembelajaran matematika.

Upaya yang dapat dilakukan agar proses pembelajaran di kelas dapat meningkatkan kemampuan pemecahan masalah siswa diantaranya memilih dan menggunakan model pembelajaran yang relevan sehingga tujuan pembelajaran dapat tercapai. Salah satu model pembelajaran yang dapat meningkatkan kemampuan pemecahan masalah matematis siswa adalah model pembelajaran Connected Mathematics Project (CMP). Model pembelajaran ini bertujuan untuk agar siswa dapat menarik kesimpulan secara logis, memperkirakan jawaban, memberikan penjelasan mengenai konsep dan prosedur jawaban yang digunakan, serta menilai kebenarannya secara matematika mengenai hubungan antara konsep dan situasi yang dihadapinya (Senimbar, 2015).

Model pembelajaran Connected Mathematics Project (CMP) ini meliputi tiga tahap yaitu launch, explore, dan summarize. Ketiga tahapan pada model pembelajaran Connected Mathematics Project (CMP) tersebut diindikasikan efektif untuk meningkatkan kemampuan pemecahan masalah matematis siswa, karena model pembelajaran ini dapat membantu siswa dan guru untuk mengembangkan pengetahuan matematika, pemahaman dan keterampilan, serta melibatkan siswa untuk berperan aktif dalam pembelajaran. Hasil penelitian Witri Lestari yang berjudul "Pengaruh Model Pembelajaran Connected Mathematics Project terhadap Kemampuan Pemecahan Masalah Matematika" di SMP Putra Bangsa. Hasil penelitian ini menunjukkan bahwa model pembelajaran Connected Mathematics Project (CMP) berpengaruh terhadap kemampuan pemecahan masalah matematis siswa dengan taraf signifikan $\alpha=0,05$ dan derajat kebebasan $=38$. Hal ini menunjukkan bahwa nilai signifikan mempuyai pengaruh terhadap variabel terikatnya (Lestari, 2017). Selain itu, hasil penelitian Senimbar yang berjudul "Penerapan Model Pembelajaran Connected Mathematics Project (CMP) untuk Meningkatkan Kemampuan Penalaran Matematis Siswa Kelas VII SMP Negeri 5 Salahutu" dengan tipe penelitian yaitu Penelitian Tindakan Kelas (PTK). Hasil penelitian tersebut menyimpulkan bahwa dengan menerapkan model pembelajaran Connected Mathematics Project (CMP), kemampuan penalaran matematis siswa kelas VII di SMP Negeri 5 Salahutu dapat meningkat dengan nilai rata-rata kelas telah mencapai standar KKM yakni 65 (Senimbar, 2015). 
Berdasarkan uraian latar belakang di atas, maka peneliti bermaksud melakukan penelitian dengan judul "Pengaruh Model Pembelajaran Connected Mathematics Project (CMP) terhadap Kemampuan Pemecahan Masalah Matematis Siswa SMP”.

\section{B. Metode Penelitian}

Jenis penelitian ini adalah penelitian Quasi Eksperiment (eksperimen semu). Pada penelitian ini terdapat dua kelompok dimana kelompok pertama adalah kelas eksperimen yaitu VIII-B dan kelompok kedua adalah kelas kontrol yaitu VIII-C. Desain penelitian yang akan digunakan yaitu Posttest Only. Adapun desain penelitian sebagai berikut:

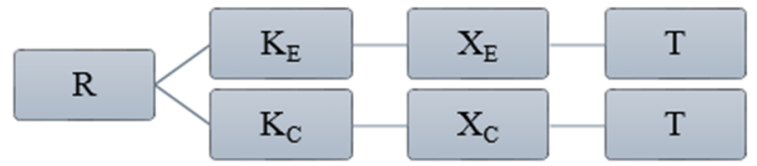

Gambar 1 Desain Penelitian

R : : Random Sampling

KE : Kelas Eksperimen yaitu VIII-B

KC : Kelas Kontrol yaitu VIII-C

XE : $\quad$ Perlakuan dengan model Connected Mathematics Project (CMP)

XC : $\quad$ Perlakuan dengan model pembelajaran konvensional

T: $\quad$ Posttest kelas eksperimen dan kelas control

Populasi yang ditetapkan pada penelitian ini adalah seluruh siswa kelas VIII tahun ajaran 2019/2020 di SMP Negeri 12 Surabaya. Dalam penelitian ini teknik yang digunakan untuk menentukan sampel menggunakan Random Sampling yaitu pengambilan sampel secara berkelompok dengan cara merandom semua kelas yang tersedia selanjutnya akan dipilih satu kelompok menjadi kelas eksperimen yaitu kelas VIII-B dan satu kelompok menjadi kelas kontrol yaitu kelas VIII-C.

Teknik pengumpulan data dalam penelitian ini menggunakan metode dokumentasi dan metode tes. Metode dokumentasi ini digunakan untuk pengambilan sampel penelitian. Peneliti mengambil data nilai ulangan harian kelas VIII kemudian dihitung rata-rata. Setelah itu dipilih dua kelompok secara acak sebagai kelas eksperimen dan kelas kontrol. Analisa data dilakukan untuk mengetahui pengaruh model pembelajaran Connected Mathematics Project (CMP) terhadap kemampuan pemecahan masalah matematis siswa dengan melihat perbedaan hasil antara kelas VIII-B dan VIII-C yang didapat dari data tes. Analisis data tes dilakukan dua tahapan yaitu uji prasyarat analisis dan uji hipotesis. Pada uji prasyarat analisis dilakukan uji normalitas dan uji homogenitas, untuk memeriksa keabsahan sampel sebagai syarat dapat dilaksanakanya analisis data. Setelah uji normalitas dan homogenitas, baru dilakukan uji hipotesis dengan menggunakan uji-t.

\section{Hasil Penelitian dan Pembahasan}

Pada penelitian ini data yang diperoleh dari 2 kelas yang terdiri dari kelas VIII-B yang diajar menggunakan model pembelajaran Connected Mathematics Project (CMP) sebanyak 37 siswa dan kelas VIII-C diajar menggunakan pembelajaran konvensional sebanyak 37 siswa. 
Data Posttest Kelas VIII-C dan Kelas VIII-B sebagai berikut:

Tabel 1 Hasil Data Posttest

\begin{tabular}{lll}
\hline Data & $\begin{array}{l}\text { Kelas } \\
\text { Eksperimen }\end{array}$ & Kontrol \\
\hline Nilai Tertinggi & 95 & 91 \\
Nilai Terendah & 78 & 74 \\
Rata-rata & 85,73 & 80,30 \\
Simpangan Baku & 4,44 & 4,14 \\
\hline
\end{tabular}

\section{Uji Normalitas}

Kriteria dalam pengujiannya adalah:

Jika $\chi_{\text {hitung }}^{2}<\chi_{\text {tabel }}^{2}$ maka data berdistribusi normal

Jika $\chi_{\text {hitung }}^{2}>\chi_{\text {tabel }}^{2}$ maka data tidak berdistribusi normal

Tabel 2 Hasil Uji Normalitas

\begin{tabular}{lll}
\hline Data & $\begin{array}{l}\text { Kelas } \\
\text { Eksperimen }\end{array}$ & Kontrol \\
\hline Jumlah Siswa & 37 & 37 \\
Rata-rata & 85,73 & 80,30 \\
Simpangan Baku & 4,44 & 4,14 \\
$\chi^{2}{ }_{\text {hitung }}$ & 4,137 & 2,977 \\
$\chi^{2}{ }_{\text {tabel }}$ & 11,070 & 11,070 \\
\hline Kesimpulan & Normal & Normal \\
\hline
\end{tabular}

\section{Uji Homogenitas}

Jika $F_{\text {hitung }} \leq F_{\text {tabel }}$, maka $H_{0}$ diterima (varians homogen)

Jika $F_{\text {hitung }}>F_{\text {tabel }}$, maka ditolak $H_{0}$ (varians tak homogen)

Tabel 3 Hasil Uji Hipotesis

\begin{tabular}{lll}
\hline Data & Kelas & \\
& Eksperimen & Kontrol \\
\hline Varians $\left(S^{2}\right)$ & 19,702 & 17,103 \\
$F_{\text {hitung }}$ & 1,152 & 1,152 \\
$F_{\text {tabel }}$ & 1,714 & 1,714 \\
\hline Kesimpulan & Homogen & Homogen \\
\hline
\end{tabular}

\section{Uji Hipotesis Penelitian}

Dalam penelitian ini menggunakan pengujian hipotesis dengan Uji-t.

Kriteria pengujian hipotesis:

$H_{o}$ diterima jika : $-t_{\text {tabel }} \leq t_{\text {hitung }} \leq t_{\text {tabel }}$

$H_{O}$ ditolak jika : $t_{\text {hitung }} \leq-t_{\text {tabel }}$ atau $t_{\text {hitung }}>t_{\text {tabel }}$.

Tabel 4 Hasil Uji Hipotesis Penelitian

\begin{tabular}{llll}
\hline Kelas & $\mathbf{N}$ & $\boldsymbol{t}_{\text {hitung }}$ & $\boldsymbol{t}_{\text {tabel }}$ \\
\hline VIII-B & 37 & 5,446 & \multirow{2}{*}{1,993} \\
VIII-C & 37 & & \\
\hline Kesimpulan & $H_{O}$ ditolak & & \\
\hline
\end{tabular}

Berdasarkan taraf signifikan 0,05 diperoleh thitung $>$ ttabel yaitu 5,446 > 1,993 maka $H_{0}$ ditolak dengan kata lain $H_{1}$ diterima yang berarti ada pengaruh model pembelajaran 
Connected Mathematics Project (CMP) terhadap kemampuan pemecahan masalah matematis siswa di SMPN 12 Surabaya.

Hasil penelitian menunjukkan bahwa kemampuan pemecahan masalah matematis siswa setelah diajarkan menggunakan model pembelajaran Connected Mathematics Project (CMP) memberikan pengaruh lebih baik daripada kemampuan pemecahan masalah matematis siswa yang diajarkan dengan menggunakan model pembelajaran konvensional. Penelitian serupa yang mengukur kemampuan pemecahan masalah matematis siswa yang diajarkan menggunakan model pembelajaran Connected Mathematics Project (CMP) juga menunjukkan hasil yang lebih tinggi daripada siswa yang diajarkan menggunakan pembelajaran konvensional (Paramita Sari \& Haji, 2020). Hal ini juga dibuktikan dengan nilai rata-rata kelas eksperimen yaitu dengan model pembelajaran Connected Mathematics Project (CMP) lebih tinggi dari kelas kontrol dengan model pembelajaran konvensional.

Pada pertemuan awal saat pelaksanaan penelitian, terdapat beberapa kendala dalam proses pembelajaran diantaranya adalah masih banyak siswa yang bingung sehingga mereka banyak bertanya kepada peneliti apa yang akan mereka tuliskan pada lembar kerja tersebut. Selain itu pengetahuan siswa terhadap materi prasyarat masih rendah, padahal model pembelajaran Connected Mathematics Project (CMP) mengharuskan siswa untuk mengeksplorasi sebanyak mungkin informasi yang didapat dari berbagai sumber dan menghubungkan permasalahan dengan pengetahuan yang sudah didapat sebelumnya. Pada pertemuan kedua hingga selesai, siswa mulai terbiasa dengan model pembelajaran Connected Mathematics Project (CMP). Siswa mulai mencari berbagai ide, merencanakan strategi untuk memecahkan masalah, dan menghubungkan permasalahan dengan pengetahuan yang sudah didapat sebelumnya. Meskipun ada beberapa siswa yang kurang konsentrasi dalam belajar.

Kegiatan pembelajaran dalam kelas eksperimen yaitu setiap pertemuan siswa diberikan Lembar Kerja Siswa (LKS) dengan tahap-tahap model pembelajaran Connected Mathematics Project (CMP). Model pembelajaran ini dapat mendorong siswa untuk mengembangkan kemampuan pemecahan masalah matematis. Sedangkan kegiatan pembelajaran dalam kelas kontrol yaitu siswa hanya mendengarkan, mencatat, serta mengerjakan tugas yang diberikan oleh peneliti. Perbedaan yang dihasilkan dari pembelajaran kelas eksperimen dan kelas kontrol terdapat pada soal tes yang mengacu pada indikator kemampuan pemecahan masalah matematis siswa. Peningkatan kemampuan pemecahan masalah matematis dengan menggunakan Connected Mathematics Project (CMP) terlihat dari analisis hasil posttest kedua kelas. Pada kelas eksperimen menunjukkan skor jawaban yang lebih baik daripada kelas kontrol.

Pada indikator memahami masalah, aktivitas yang dilakukan siswa adalah memahami permasalahan dalam soal dengan tepat dan menyebutkan informasi apa saja yang diketahui, ditanyakan, dan diperlukan untuk merancang model matematikanya. Berdasarkan perhitungan yang dilakukan pada indikator memahami masalah untuk kelas eksperimen memperoleh nilai sebesar 88,85\% sedangkan pada kelas kontrol memperoleh nilai sebesar 76,35\%. Dari perolehan nilai kedua kelas tersebut dapat dilihat bahwa kemampuan memahami masalah antara kelas eksperimen lebih tinggi daripada kelas kontrol dengan selisih nilai 12,5\%. Hal ini dikarenakan siswa pada kelas eksperimen terbiasa menghadapi permasalahan sehingga siswa lebih mudah dalam memahami permasalahan dalam soal.

Pada indikator membuat rencana penyelesaian masalah, aktivitas siswa yaitu membuat rencana penyelesaian masalah dengan benar yang mengarah ke penyelesaian masalah yang benar. Berdasarkan perhitungan, untuk kelas eksperimen memperoleh nilai sebesar $85,13 \%$ sedangkan kelas kontrol 70,43\%. Dari perolehan nilai tersebut, dapat dilihat bahwa kemampuan pemecahan masalah kelas eksperimen lebih tinggi daripada kelas kontrol dengan selisih nilai $14,7 \%$. Hal ini dikarenakan pada kelas eksperimen yang sudah terbiasa memahami masalah sehingga dapat membuat rencana atau strategi penyelesaian masalah dengan tepat. 
Pada indikator melakukan rencana/perhitungan, aktivitas siswa adalah menghitung penyelesaian masalah dari rencana penyelesaian yang sudah dibuat dengan tepat dan benar. Berdasarkan perhitungan, indikator melakukan rencana/perhitungan inilah yang mempunyal selisih nilai yang tidak terlalu besar daripada indikator lain. Pada kelas eksperimen memperoleh nilai sebesar 70,94\% sedangkan kelas kontrol yaitu 64,86\%. Hal ini disebabkan karena siswa dari kelas eksperimen maupun kelas kontrol kurang teliti dalam melakukan perhitungan sehingga terjadi kesalahan dalam memperoleh hasil jawaban. Namun pada indikator melakukan rencana/perhitungan ini dapat dilihat bahwa perhitungan nilai kelas eksperimen lebih tinggi daripada kelas kontrol dengan selisih yaitu 6,08\%

Pada indikator memeriksa kembali, aktivitas siswa yaitu memeriksa kembali hasil perhitungan yang telah dilakukan. Pada indikator ini telah dilakukan perhitungan baik untuk kelas eksperimen maupun kelas kontrol masing-masing sebesar 80,74\% dan 75,33\% dengan selisih nilai sebesar $5,41 \%$. Kelas eksperimen memperoleh nilai yang lebih besar dibandingkan dengan kelas kontrol, karena pada kelas kontrol belum terbiasa menganalisis dan mengevalusi hasil proses pemecahan masalah.

Pencapaian kemampuan siswa dalam kemampuan pemecahan matematis pada pembelajaran Matematika didukung oleh pembelajaran yang dapat mengarahkan siswa untuk menggunakan kemampuan pemecahan masalah tersebut. Model pembelajaran Connected Mathematics Project (CMP) terbukti dapat meningkatkan kemampuan pemecahan masalah matematis siswa. Hal ini dibuktikan dengan ketercapaian untuk setiap indikator kemampuan pemecahan masalah matematis siswa pada kelas eksperimen mempuyai nilai yang lebih besar daripada kelas kontrol. Selain itu tahapan-tahapan pada model pembelajaran Connected Mathematics Project (CMP) membuat siswa lebih berperan aktif dalam pembelajaran dan menyampaikan gagasan atau ide-ide yang sesuai dalam menyelesaikan masalah yang diberikan. Kebiasaan belajar siswa yang selama ini pasif dan hanya mendengarkan apa yang disampaikan oleh guru sudah berubah, maka hasil penelitian ini sejalan dengan teori Glenda Lappan et. Al. yang menyatakan bahwa model pembelajaran Connected Mathematics Project (CMP) membantu siswa dalam menumbuhkan pengetahuan mereka yang mencakup kemampuan untuk menentukan dan memecahkan masalah dengan alasan, wawasan, keahlian menciptakan sesuatu yang baru, dan kemampuan teknis. Siswa juga dapat melakukan pendekatan dalam beberapa cara, menggunakan strategi yang berbeda dalam menemukan solusi, serta menghubungkan ideide penting matematika lainnya.

Hasil penelitian ini sejalan dengan penelitian serupa dengan mengimplementasikan CMP dalam aktivitas pembelajaran pada proses kegiatan dengan siswa (Paramita Sari \& Haji, 2020), (Isnani et al., 2021).

\section{Kesimpulan dan Saran}

Berdasarkan hasil penelitian yang dilakukan mengenai penerapan model pembelajaran Connected Mathematics Project (CMP) terhadap kemampuan pemecahan masalah matematis siswa di SMP Negeri 12 Surabaya diperoleh kesimpulan bahwa terdapat pengaruh model pembelajaran Connected Mathematics Project (CMP) terhadap kemampuan pemecahan masalah matematis siswa SMP. Kemampuan pemecahan masalah matematis siswa yang diajarkan dengan model pembelajaran CMP lebih tinggi dari siswa yang diajarkan dengan model pembelajaran konvensional yang ditunjukkan dengan perbedaan nilai rata-rata yang signifikan. Indikator kemampuan pemecahan masalah matematis siswa yang paling baik adalah pada indikator memahami masalah baik dari kelas eksperimen dan kelas kontrol. Berdasarkan hasil ketercapaian setiap indikator kemampuan pemecahan masalah matematis yang telah ditentukan, kelas eksperimen mempunyai hasil pencapaian yang lebih tinggi daripada kelas kontrol. Selain itu peningkatan kemampuan pemecahan masalah matematis siswa dapat menuntaskan hasil belajar siswa pada mata pelajaran matematika. 
Berdasarkan kesimpulan penelitian, terdapat beberapa saran peneliti terkait hasil penelitian, diantaranya adalah sebagai berikut:

1. Model pembelajaran Connected Mathematics Project (CMP) diharapkan dapat menjadi salah satu variasi pembelajaran yang dapat diterapkan di dalam kelas. Selain itu model pembelajaran Connected Mathematics Project (CMP) sebaiknya lebih sering diterapkan guna menumbuhkan kemampuan pemecahan masalah matematis siswa.

2. Diharapkan siswa lebih aktif dalam mengikuti pembelajaran dan lebih meningkatkan kemampuan pemecahan masalah matematis agar hasil belajar lebih meningkat secara optimal.

3. Dengan adanya penelitian terkait model pembelajaran Connected Mathematics Project (CMP) ini diharapkan penelitian ini dapat digunakan sebagai acuan atau bekal penelitian di masa mendatang bagi peneliti yang lain.

\section{DAFTAR PUSTAKA}

Arikunto, S. (2016). Dasar-dasar Evaluasi Pendidikan (2 ed.). Jakarta: Bumi Aksara.

Astutik, E. P., \& Fitriatien, S. R. (2016). Metode Statistika. Surabaya: Universitas PGRI Adi Buana Surabaya.

Hadi, S., \& Radiyatul. (2014, Februari). Metode Pemecahan Masalah menurut Polya untuk Mengembangkan Kemampuan Siswa dalam Pemecahan Masalah Matematis di Sekolah Menengah Pertama. EDU-MAT Jurnal Pendidikan Matematika, 2, 53-61.

Indriani, R., Puspita, A. M. I., Ninawati, M., Handayani, H., \& Agusfianuddin. (2019). Contextual Teaching And Learning Untuk Meningkatkan Kemampuan Pemahaman Konsep Pecahan. KALAMATIKA Jurnal Pendidikan Matematika, 4(1), 109-116.

Isnani, I., Masykur, R., \& Andriani, S. (2021). Applying The Integrated Curriculum Concept Through Connected Mathematics Project (Cmp) Learners To Mathematical Communication Skills. Jurnal THEOREMS (The Original Research of Mathematics), 5(2). https://doi.org/10.31949/th.v5i2.2598

Jatmiko, J. (2018). Kesulitan Siswa Dalam Memahami Pemecahan Masalah Matematika. JIPMat. https://doi.org/10.26877/jipmat.v3i1.2285

Lappan, G. (2002). Getting to Know Connected Mathematics : An Implementation Guide. Michigan State University.

Lestari, W. (2017). Pengaruh Model Pembelajaran Connected Mathematics Project terhadap Kemampuan Pemecahan Masalah Matematika. Jurnal Kajian Pendidikan Matematika.

Mulyoko. (2014). Pengaruh Model Pembelajaran Connected Mathematics Project (CMP) terhadap Kemampuan Representasi Matematis Siswa. Jakarta: Universitas Islam Negeri Syarif Hidayatullah.

Mulyono, H. (2015). Interpolasi dalam Perhitungan Statistik. Jakarta: Universitas Muhammadiyah Prof. Dr. Hamka. 
NCTM. (1989). Curriculum and Evaluation Standards for School Mathematics. Reston Virginia: NCTM.

NCTM, N. (2000). Principles and Standards for School Mathematics. United States of America: National Council of Teachers of Mathematics.

Paramita Sari, W., \& Haji, S. (2020). Pengaruh Model Pembelajaran Conncted Mathematics Project (CMP) Terhadap Kemampuan Pemahaman Konsep Matematika. In Jurnal Pendidikan Matematika Raflesia (Vol. 05, Issue 01).

Polya, G. (1973). How to Solve It. New York: Stanford University.

Priatna, B. A. (2008). Uji Coba Instrumen Penelitian dengan Menggunakan MS Excel dan SPSS. Bandung: Direktori File UPI.

Safitri, F. A. (2017). Profil Kemampuan Penalaran Matematis dan Keterampilan Sosial Siswa dalam Pembelajaran Connected Mathematics Project ditinjau dari Kemampuan Matematika Siswa. Surabaya: UIN Sunan Ampel Surabaya.

Senimbar. (2015). Penerapan Model Pembelajaran Connected Mathematics Project untuk Meningkatkan Kemampuan Penalaran Matematis Siswa Kelas VII SMP Negeri 5 Salahutu. Bimafika.

Septiani, R. (2014). Peningkatan Kemampuan Pemecahan Masalah Matematika Siswa Kelas VIIIF melalui Model Pembelajaran The Power of Two di SMP Negeri 5 Purwokerto. Jurnal Pendidikan Matematika.

Wahyuningtias, N. (2019). Pengaruh Model Pembelajaran SQ3R terhadap Hasil Belajar Siswa Kelas VII SMPN 1 Sukodono. Surabaya: Universitas PGRI Adi Buana Surabaya. 